\title{
Broad-scale movements of juvenile white sharks Carcharodon carcharias in eastern Australia from acoustic and satellite telemetry
}

\author{
B. D. Bruce ${ }^{1}$, D. Harasti ${ }^{2}$, K. Lee ${ }^{2,3,4}$, C. Gallen ${ }^{2}$, R. Bradford ${ }^{1, *}$ \\ ${ }^{1}$ CSIRO Oceans and Atmosphere, Hobart, TAS 7004, Australia \\ ${ }^{2}$ Fisheries Research, NSW Department of Primary Industries, Nelson Bay, NSW 2315, Australia \\ ${ }^{4}$ Sydney Institute of Marine Science, Mosman, NSW 2088, Australia \\ ${ }^{4}$ Department of Biological Sciences, Macquarie University, North Ryde, NSW 2113, Australia
}

ABSTRACT: The advent of electronic tagging has seen vast advances in our understanding of marine top-order predator movements over broad spatial scales. However, most studies are restricted to short temporal scales. We examined movements of 43 juvenile white sharks Carcharodon carcharias (1.7-3.2 m total length) in eastern Australia via satellite-linked radio tags (SLRTs) and internally implanted long-life acoustic tags, the latter monitored by receiver arrays spanning a continental scale and across international boundaries. Although SLRT data were restricted to less than $2 \mathrm{yr}$, the study registered approximately 182000 detections of acoustic-tagged white sharks on 287 receivers over $7 \mathrm{yr}$, with individual tracking periods of up to 5 yr. Data reveal complex movement patterns over distances of thousands of kilometres and $13^{\circ}$ of latitude, with sharks ranging from the southern Great Barrier Reef, Queensland, to Tasmania and across the Tasman Sea to New Zealand. Sharks showed a variety of movement patterns, including annual fidelity to spatially restricted nursery areas, directed seasonal coastal movements, intermittent areas of temporary nearshore residency and offshore excursions into the Tasman Sea. Movements east to west through Bass Strait were restricted, further supporting the 2-population model for the species in Australian waters. The latitudinal range of movements increased with years at liberty, and female sharks were more commonly encountered than males in nearshore waters. Long-term monitoring of acoustic-tagged sharks via data sharing through collaborative national and international receiver arrays offers future promise to

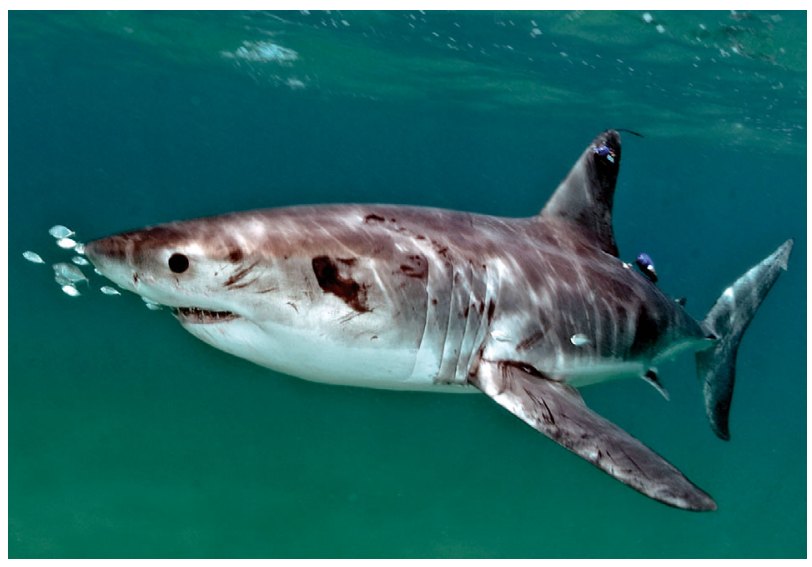

Juvenile white sharks off eastern Australia tracked using satellite-linked radio tags and long-life acoustic tags

Photo: Justin Gilligan

examine movements over periods relevant to ontogenetic changes and at scales providing context to interannual variability.

KEY WORDS: Nursery area $\cdot$ Migration · Australia's Integrated Marine Observing System · IMOS

\section{INTRODUCTION}

The rapid expansion and widespread use of electronic tags since the late 1980 s has provided a wealth of information on the movements and behav- 
iours of marine animals, especially apex predators (Arnold \& Dewar 2001, Heupel et al. 2015). The combination of satellite-based tag technology and long-life acoustic tags has allowed researchers to examine both fine-scale movements and broadscale migrations for many marine species, often highlighting previous misconceptions about these aspects of life history (Heupel et al. 2006, Crossin et al. 2017). Species once considered to be relatively resident have been found to be highly migratory and cover enormous distances; examples include sixgill shark Hexanchus griseus (Andrews et al. 2010), basking shark Cetorhinus maximus (Sims et al. 2005) and white sturgeon Acipenser transmontanus (Welch et al. 2006). Other widely distributed species have been shown to display strong site fidelity with small home ranges, such as snapper Chrysophrys auratus (Harasti et al. 2015) and blue groper Achoerodus viridis (Lee et al. 2014).

Acoustic and satellite tracking of elasmobranchs is now considered common practice, with numerous studies deploying tags to track movements and residency (Chapman et al. 2015). Sustained, long-term monitoring of spatial dynamics in shark populations plays an important role in their conservation biology, risk management and protection (Hueter et al. 2005, Heupel et al. 2007, Knip et al. 2010). Some sharks display strong site fidelity (wobbegong shark Orectolobus maculatus, Lee et al. 2015; leopard shark Triakis semifasciata, Carlisle \& Starr 2009), while others show seasonal movement patterns (speartooth shark Glyphis glyphis, Lyon et al. 2017; sixgill shark Hexanchus griseus, Andrews et al. 2010). Others undertake large migrations (whale shark Rhincodon typus, Wilson et al. 2006; basking shark Cetorhinus maximus, Doherty et al. 2017).

One species with a global distribution in temperate and subtropical marine waters of both hemispheres, and which travels large distances, is the white shark Carcharodon carcharias (Last \& Stevens 2009). It is most often observed over the continental shelf, often around continental islands (Bruce 2008), but can be found close inshore within the surf zone, as well as entering some estuaries and large bays (Harasti et al. 2017b, Oñate-González et al. 2017). Long-term tracking studies have also revealed that $C$. carcharias frequent open ocean regions and undertake oceanic basin-scale migrations (Bonfil et al. 2005, Weng et al. 2007a, Domeier \& Nasby-Lucas 2008). White sharks tagged off California (USA) have been recorded as far west as the Hawaiian Islands (Weng et al. 2007b). Duffy et al. (2012) identified migrations between New Zealand, Australia, New Caledonia, Vanuatu and Tonga, whilst migrations between South Africa and north-western Australia have also been recorded (Bonfil et al. 2005).

Despite their global distribution and propensity for long-distance movements, several discrete populations of C. carcharias exist (Pardini et al. 2000, Gubili et al. 2012). White sharks in the Australasian region differ genetically from other populations (Pardini et al. 2000), and data suggest there are 2 populations in southern Australia separated east and west by Bass Strait (Blower et al. 2012). This Australasian population structure is further supported by acoustic and satellite tagging studies (Bruce \& Bradford 2012, Duffy et al. 2012, McAuley et al. 2017).

Monitoring the spatial dynamics of apex predators, such as white sharks, is challenging due to their low abundance and wide-ranging distribution. For this reason, most studies have relied on a few locations where the species tends to be more easily found, such as pinniped colonies (Martin et al. 2005, Robbins 2007, Francis et al. 2015). In Australia, white sharks are known to occur from Northwest Cape, Western Australia, through southern waters to the central coast of Queensland (Last \& Stevens 2009). In eastern Australia, studies have been focussed at 2 nursery areas where juvenile white sharks $(<3 \mathrm{~m})$ can be found in relatively high abundance (Bruce \& Bradford 2012, Harasti et al. 2017a). An analysis of short-term (less than 1 yr) satellite tracking of juvenile sharks from these nursery areas supported their largely shelf-based distribution, but also identified some off-shelf excursions and transTasman Sea movement (Bruce \& Bradford 2012). However, the long-term movement patterns of juvenile white sharks off eastern Australia are yet to be documented.

Apex predators can potentially have a profound influence on their surrounding ecosystem (Ruppert et al. 2013). Understanding the extent of their movements and habitat use will assist with conserving such species, managing marine communities and, in the case of white sharks, the prospect of minimising threats to human safety (McAuley et al. 2017). Using a combination of acoustic telemetry and satellite tracking data, this project documents the large-scale movements of juveniles over a $7 \mathrm{yr}$ period along the east coast of Australia. Specifically, this study aimed to (1) examine the distribution and movements of juvenile white sharks over a range of spatial and temporal scales, (2) assess differences in movements and habitat use between sexes and (3) identify areas of residency, in particular those outside of the defined nursery areas. 


\section{MATERIALS AND METHODS}

\subsection{Data acquisition}

Juvenile white sharks were tagged within 2 regions of eastern Australia: Port Stephens, central New South Wales (NSW; 32 $42.12^{\prime} \mathrm{S}, 152^{\circ} 12.18^{\prime} \mathrm{E}$ ) and near Corner Inlet in southeast Victoria $\left(38^{\circ}\right.$ $\left.48.42^{\prime} \mathrm{S}, 146^{\circ} 31.8^{\prime} \mathrm{E}\right)$. Tagging occurred as part of a portfolio of studies designed to determine the sharks' overall habitat use, movements and survival, as well as to provide input parameters for a population model (Bradford et al. 2012, Harasti et al. 2017b, Hillary et al. 2018). Capture and tagging protocols followed Bruce \& Bradford (2012) and Harasti et al. (2017b), whereby sharks were either visually located from a vessel near the surf zone of local beaches, presented a bait, hooked, then loaded into an in-water stretcher for tagging; or they were captured on monitored surface-buoyed setlines. An acoustic tag (Vemco, V16-6x, $69 \mathrm{kHz}$ ) was surgically implanted into the peritoneal cavity of each shark via a 20$25 \mathrm{~mm}$ incision which was sutured closed using PDS II Z195T sutures (Ethicon ${ }^{\mathrm{TM}}$ ). Total length (TL) and fork length were measured to the nearest $\mathrm{cm}$, sex was determined by the presence or absence of claspers, the hook was removed, and the shark was released. Several sharks were additionally fitted with a satellite-linked radio tag (SLRT; either Wildlife Computers ${ }^{\circledR}$ SPOT or SPLASH tags) attached to their first dorsal fin (Table 1). Analyses are restricted to movement data based on acoustic tag detection and satellite-derived locations.

Acoustic detections were analysed over a $7 \mathrm{yr}$ period from October 2008 to December 2015. Data were retrieved directly from receivers deployed as part of the project portfolio in the vicinity of the 2 tagging regions (see Harasti et al. 2017b for details of listening station arrays). These data were supplemented with data extracted from Australia's Integrated Marine Observing System (IMOS) online database, which stores detections from a collective of multi-institutional receiver deployments in Australian waters (https://animaltracking. aodn.org.au). Single (non-consecutive) detections were removed from analyses to minimise the likelihood of false detections. Supplementary data on white shark captures in the Queensland and NSW shark control programmes (SCPs) were sourced from on-line catch statistics and reports (www. daf.qld.gov.au/business-priorities/fisheries/sharkcontrol-program and www.sharksmart.nsw.gov.au/ shark-nets, respectively).

\subsection{Data analyses}

The direction and timing of movements along the east coast were determined from acoustic tag detections using the latitude of the 3 IMOS cross-shelf lines of receivers as references: Coffs Harbour ( $\left.29^{\circ} 55.8^{\prime} \mathrm{S}\right)$, Bondi $\left(33^{\circ} 55.8^{\prime} \mathrm{S}\right)$ and Narooma (36 $\left.15.6^{\prime} \mathrm{S}\right)$ (Fig. 1). The timing and direction of travel of each shark was determined by 1 of the following 3 methods. A shark was deemed to have crossed the latitude of a crossshelf line if it was (1) detected by receivers on that line as well as by receivers north and south within 1 mo of the detection on the line; (2) if it had been detected by receivers on both the north and south side of the line within any $30 \mathrm{~d}$ period but not on the line; or (c) if satellite tracking data from fin-mounted SLRTs (see below) indicated travel across the latitude of the line irrespective of the shark's detection on the line. Direction of travel was determined by the chronological sequence of detections from north to south (southerly travel) or from south to north (northerly travel). Data suggesting travel by individual sharks that fell outside of these definitions were not included in analyses to avoid bias where sharks may have made multiple crossings of the reference latitudes but had remained undetected or because the timing and direction of crossing could not be adequately determined.

Transmissions from SLRTs were extracted from the ARGOS Collection and Location System (Witt et al. 2010). Satellite-derived positions are reliant on the shark surfacing and exposing the tag to air in order to communicate with the ARGOS satellite constellation. This can lead to bias in determining the amount of time spent in a location when multiple fixes are received over short periods of time followed by lengthy periods where few or no transmissions are received. To overcome this, we first calculated an average daily position $\left(\mathrm{ADP}_{\text {sat }}\right)$ for each shark, using the mean latitude and longitude for all accepted positions per calendar day (00:00$23: 59 \mathrm{~h}$ local time). We followed the methods of Bruce et al. (2006) to accept positions for analyses. We then used linear interpolation, implemented in the R-package 'adehabitatLT' (Calenge 2006), to normalise the transmission frequency by generating points at $24 \mathrm{~h}$ intervals along track gaps of $\leq 5 \mathrm{~d}$. Where gaps $>5 \mathrm{~d}$ were encountered, the track was split into separate sections (Queiroz et al. 2016) A $5 \mathrm{~d}$ period was chosen based on the recorded movement rates of sharks when travelling to minimise reconstructing unrealistically linear paths over longer periods. 
Table 1. Details of tagged white sharks and their periods of tracking. Period monitored refers to the time period between date of first and last detection; total time at liberty refers to the time period between the date of tagging and date of last detection. TL: total length; Ac: acoustic tag; SLRT: satellite-linked radio tag; NA: not applicable (shark was not fitted with tag type); ND: no data received. Dates are given as (d/mo/yr)

\begin{tabular}{|c|c|c|c|c|c|c|c|c|c|c|}
\hline \multirow{2}{*}{ Shark } & \multirow{2}{*}{$\begin{array}{l}\mathrm{TL} \\
(\mathrm{m})\end{array}$} & \multirow[t]{2}{*}{ Sex } & \multirow{2}{*}{$\begin{array}{l}\text { Tagging } \\
\text { location }\end{array}$} & \multirow{2}{*}{$\begin{array}{l}\text { Tags } \\
\text { monitored (d) }\end{array}$} & \multirow[t]{2}{*}{ Tagged } & \multicolumn{2}{|c|}{ — Last detection — } & \multicolumn{2}{|c|}{- Period -} & \multirow{2}{*}{$\begin{array}{l}\text { Time at } \\
\text { liberty }(\mathrm{d})\end{array}$} \\
\hline & & & & & & $\mathrm{Ac}$ & SLRT & $\mathrm{Ac}$ & SLRT & \\
\hline 1 & 2.3 & F & Port Stephens & $\mathrm{Ac}$ & $28 / 10 / 08$ & $11 / 06 / 09$ & NA & 227 & NA & 227 \\
\hline 2 & 2.3 & $\mathrm{~F}$ & Port Stephens & $\mathrm{Ac}_{\mathrm{i}} \mathrm{SLRT}$ & 28/10/08 & 26/04/11 & $30 / 12 / 08$ & 749 & 64 & 911 \\
\hline 3 & 1.8 & $\mathrm{~F}$ & Port Stephens & $\mathrm{Ac}_{\text {; }} \mathrm{SLRT}$ & $28 / 10 / 08$ & $20 / 08 / 11$ & $10 / 06 / 09$ & 1025 & 226 & 1027 \\
\hline 4 & 2.3 & $\mathrm{~F}$ & Port Stephens & $\mathrm{Ac}$ & $28 / 10 / 08$ & $9 / 09 / 11$ & NA & 969 & NA & 1047 \\
\hline 5 & 2.2 & $\mathrm{~F}$ & Port Stephens & $\mathrm{Ac}_{;} \mathrm{SLRT}$ & $30 / 10 / 08$ & $27 / 01 / 10$ & $30 / 10 / 08$ & 383 & 1 & 455 \\
\hline 6 & 2.4 & M & Port Stephens & $\mathrm{Ac}$ & $31 / 10 / 08$ & $17 / 07 / 09$ & NA & 170 & NA & 260 \\
\hline 7 & 2.1 & $\mathrm{~F}$ & Port Stephens & $\mathrm{Ac}$ & $31 / 10 / 08$ & $3 / 10 / 09$ & NA & 138 & NA & 338 \\
\hline 8 & 2.1 & $\mathrm{M}$ & Port Stephens & $\mathrm{Ac}_{\mathrm{i}} \mathrm{SLRT}$ & $28 / 10 / 09$ & $10 / 01 / 10$ & $27 / 04 / 10$ & 1 & 182 & 182 \\
\hline 9 & 2.0 & $\mathrm{M}$ & Port Stephens & $\mathrm{Ac}_{\mathrm{i}} \mathrm{SLRT}$ & 28/10/09 & $13 / 01 / 10$ & 21/11/09 & 3 & 25 & 78 \\
\hline 10 & 2.4 & $\mathrm{~F}$ & Port Stephens & $\mathrm{Ac}_{\mathrm{i}} \mathrm{SLRT}$ & 28/10/09 & $25 / 12 / 13$ & 1/05/10 & 1469 & 186 & 1520 \\
\hline 11 & 2.3 & $\mathrm{M}$ & Port Stephens & $\mathrm{Ac}_{\mathrm{i}} \mathrm{SLRT}$ & 29/10/09 & $28 / 04 / 10$ & 8/04/10 & 79 & 162 & 182 \\
\hline 12 & 2.1 & $\mathrm{~F}$ & Port Stephens & $\mathrm{Ac}_{;} \mathrm{SLRT}$ & 29/10/09 & $4 / 10 / 14$ & $10 / 01 / 10$ & 1686 & 74 & 1802 \\
\hline 13 & 2.4 & $\mathrm{~F}$ & Port Stephens & $\mathrm{Ac}_{;} \mathrm{SLRT}$ & $30 / 10 / 09$ & $4 / 03 / 11$ & $6 / 05 / 10$ & 485 & 189 & 491 \\
\hline 14 & 2.2 & $\mathrm{~F}$ & Port Stephens & $\mathrm{Ac}$ SLRT & $30 / 10 / 09$ & $16 / 10 / 11$ & $26 / 01 / 10$ & 638 & 89 & 717 \\
\hline 15 & 2.1 & F & Port Stephens & $\mathrm{Ac}$ & $30 / 10 / 09$ & $20 / 06 / 14$ & NA & 1605 & NA & 1695 \\
\hline 16 & 2.2 & $\mathrm{~F}$ & Port Stephens & $\mathrm{Ac}$ & $27 / 10 / 10$ & $7 / 12 / 10$ & NA & 1 & NA & 42 \\
\hline 17 & 2.2 & $\mathrm{~F}$ & Port Stephens & $\mathrm{Ac}$ & $27 / 10 / 10$ & 16/01/11 & NA & 6 & NA & 82 \\
\hline 18 & 2.2 & $\mathrm{~F}$ & Port Stephens & $\mathrm{Ac}_{;} \mathrm{SLRT}$ & $27 / 10 / 10$ & $27 / 05 / 11$ & $2 / 01 / 11$ & 169 & 68 & 213 \\
\hline 19 & 1.9 & M & Port Stephens & $\mathrm{Ac}_{\mathrm{i}} \mathrm{SLRT}$ & $27 / 10 / 10$ & $28 / 10 / 12$ & $5 / 02 / 11$ & 677 & 102 & 733 \\
\hline 20 & 2.2 & M & Port Stephens & $\mathrm{Ac}$ & $27 / 10 / 10$ & $12 / 02 / 13$ & NA & 811 & NA & 840 \\
\hline 21 & 2.5 & $\mathrm{M}$ & Port Stephens & $\mathrm{Ac}$ & $29 / 10 / 10$ & 28/04/14 & NA & 1182 & NA & 1278 \\
\hline $22^{\mathrm{a}}$ & 2.8 & $\mathrm{~F}$ & Corner Inlet & $\mathrm{Ac}$ & $14 / 12 / 10$ & ND & $1 / 06 / 12$ & ND & 536 & 536 \\
\hline 23 & 2.4 & M & Port Stephens & $\mathrm{Ac}$ & $25 / 10 / 11$ & $26 / 11 / 11$ & NA & 31 & NA & 33 \\
\hline 24 & 2.2 & $\mathrm{~F}$ & Port Stephens & $\mathrm{Ac} ; \mathrm{SLRT}$ & $25 / 10 / 11$ & $5 / 12 / 11$ & $28 / 02 / 12$ & 1 & 127 & 127 \\
\hline 25 & 1.7 & M & Port Stephens & $\mathrm{Ac}_{\mathrm{i}} \mathrm{SLRT}$ & $25 / 10 / 11$ & $14 / 12 / 11$ & $16 / 01 / 12$ & 50 & 84 & 84 \\
\hline 26 & 2.3 & $\mathrm{~F}$ & Port Stephens & $\mathrm{Ac}$ & $25 / 10 / 11$ & 6/09/12 & NA & 317 & NA & 318 \\
\hline 27 & 2.2 & $\mathrm{~F}$ & Port Stephens & $\mathrm{Ac}$ & $25 / 10 / 11$ & $24 / 10 / 13$ & NA & 730 & NA & 731 \\
\hline 28 & 2.3 & $\mathrm{M}$ & Port Stephens & $\mathrm{Ac}$ & $25 / 10 / 11$ & $10 / 10 / 11$ & NA & 1082 & NA & 1082 \\
\hline 29 & 2.1 & $\mathrm{~F}$ & Port Stephens & $\mathrm{Ac}$ & $25 / 10 / 11$ & $20 / 11 / 14$ & NA & 1123 & NA & 1123 \\
\hline 30 & 2.4 & $\mathrm{~F}$ & Port Stephens & $\mathrm{Ac}_{\mathrm{i}} \mathrm{SLRT}$ & $25 / 10 / 11$ & $28 / 11 / 14$ & 28/12/11 & 1131 & 65 & 1131 \\
\hline 31 & 2.3 & $\mathrm{M}$ & Port Stephens & $\mathrm{Ac}_{;} \mathrm{SL}$ & 10 & $23 / 1$ & 16/ & 431 & 158 & 440 \\
\hline 32 & 2.8 & $\mathrm{~F}$ & Port Stephens & Ac; SLRT & $10 /$ & $31 / 1$ & $11 / 07 / 13$ & 1176 & 275 & 1178 \\
\hline 33 & 2.6 & $\mathrm{~F}$ & Port Stephens & $\mathrm{Ac}_{\mathrm{i}} \mathrm{SLRT}$ & $19 /$ & $17 / 0$ & $3 / 07 / 13$ & 150 & 197 & 197 \\
\hline 34 & 2.2 & $\mathrm{~F}$ & Port Stephens & $\mathrm{Ac}_{\mathrm{i}} \mathrm{SLRT}$ & 19/12/12 & $6 / 12 / 15$ & $15 / 03 / 13$ & 1081 & 87 & 1083 \\
\hline 35 & 3.2 & $\mathrm{~F}$ & Port Stephens & $\mathrm{Ac}_{\mathrm{i}} \mathrm{SLRT}$ & $20 / 12 / 12$ & $27 / 06 / 13$ & $12 / 03 / 13$ & 156 & 83 & 190 \\
\hline 36 & 1.9 & M & Port Stephens & $\mathrm{Ac}$ & $31 / 10 / 13$ & $18 / 10 / 15$ & NA & 709 & NA & 718 \\
\hline $37^{b}$ & 2.0 & M & Corner Inlet & $\mathrm{Ac}$ & $5 / 12 / 13$ & $18 / 11 / 14$ & NA & 204 & NA & 349 \\
\hline $38^{\mathrm{c}}$ & 2.1 & M & Corner Inlet & $\mathrm{Ac}$ & $5 / 12 / 13$ & ND & NA & ND & NA & NA \\
\hline 39 & 1.7 & M & Corner Inlet & $\mathrm{Ac}$ & $24 / 02 / 14$ & $27 / 12 / 15$ & NA & 671 & NA & 672 \\
\hline 40 & 2.7 & $\mathrm{~F}$ & Port Stephens & $\mathrm{Ac}_{\text {; }} \mathrm{SLRT}$ & $14 / 11 / 14$ & $21 / 12 / 15$ & $16 / 05 / 15$ & 388 & 184 & 403 \\
\hline 41 & 1.9 & $\mathrm{~F}$ & Port Stephens & Ac; SLRT & $24 / 11 / 14$ & $26 / 12 / 15$ & $15 / 05 / 15$ & 399 & 173 & 398 \\
\hline $42^{\mathrm{d}}$ & 1.9 & F & Port Stephens & $\mathrm{Ac}$ & $10 / 11 / 15$ & ND & NA & ND & NA & NA \\
\hline $43^{\mathrm{e}}$ & 2.2 & F & Port Stephens & $\mathrm{Ac}$ & $3 / 11 / 15$ & ND & NA & ND & NA & NA \\
\hline \multicolumn{11}{|c|}{$\begin{array}{l}\text { b Shark was captured and killed in the New South Wales Shark Control Program (NSW SCP) bather protection net at Bondi } \\
\text { Beach on 19/11/2014 }\end{array}$} \\
\hline \multicolumn{11}{|c|}{$\begin{array}{l}{ }^{c} \text { Acoustic tag was never detected but shark was captured } 29 \mathrm{~d} \text { after tagging on 2/1/2014 in a commercial fish trawl and } \\
\text { released }\end{array}$} \\
\hline \multicolumn{11}{|c|}{$\begin{array}{l}\text { dShark was captured and killed in an NSW SCP bather protection net at Blacksmiths Beach on 04/12/2015, i.e. } 25 \text { d after } \\
\text { tagging }\end{array}$} \\
\hline eFirst d & & & & & & & & & & \\
\hline
\end{tabular}

Similarly, we calculated an ADP from all acoustic detections $\left(\mathrm{ADP}_{\mathrm{ac}}\right)$ analogous to the 'centre of activity' weighted mean position algorithm estimation by Simpfendorfer et al. (2002) but using the same 00:00-
$23: 59 \mathrm{~h}$ period. Due to the highly variable distances between acoustic receiver deployments and, in some cases, their intermittent deployment schedules, no attempt was made to interpolate between $\mathrm{ADP}_{\mathrm{ac}}$ 


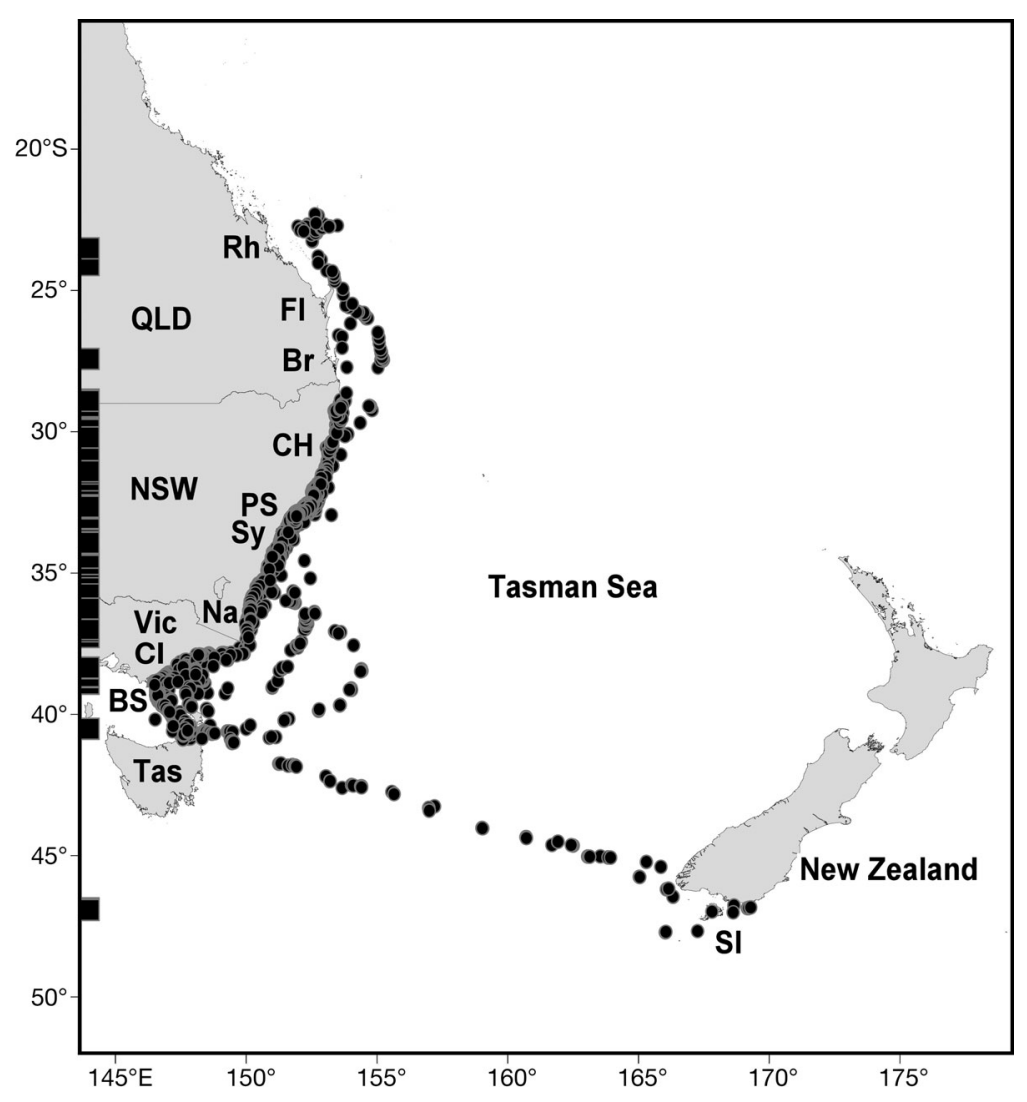

Fig. 1. Broad-scale range of movements of juvenile white sharks tagged off eastern Australia based on all accepted satellite-linked radio tag data (black dots). For comparison, the black squares at left indicate the latitude of acoustic receivers that detected tagged sharks along the east Australian coast and off southern New Zealand. Integrated Marine Observing System cross shelf lines of receivers are positioned at Coffs Harbour (CH), Bondi in Sydney (Sy) and Narooma (Na). Rh: Rockhampton; FI: Fraser Island; Br: Brisbane; PS: Port Stephens CI: Corner Inlet; BS: Bass Strait; SI: Stewart Island; QLD: Queensland; NSW: New South Wales; Vic: Victoria; Tas: Tasmania

locations. Chi-squared $\left(\chi^{2}\right)$ analysis was used to compare overall sex ratio data.

The range of north-south movement along the coast was estimated by subtracting the lowest (northernmost) latitude from the highest (southernmost) latitude registered by each individual shark during the study, resulting in the metric $\Delta_{\text {Lat }}$. Given the uncertainty in growth rates of juvenile white sharks (see Andrews \& Kerr 2015), we did not attempt to estimate individual changes in size over the course of multiyear tracking periods. However, to determine if the latitudinal range of movement changed with sharks' age/size, $\Delta_{\text {Lat }}$ was assessed against time at liberty. Analyses were restricted to juvenile sharks $<2.5 \mathrm{~m}$ TL at capture $(\mathrm{n}=22)$, which were tracked for periods greater than 300 d. Larger sharks (2.5-3.2 m TL; $\mathrm{n}=$ 4) were excluded from analyses to avoid comparisons with individuals that were already approaching sub-adult size at tagging (see Bruce \& Bradford 2012 for life-history definitions).

The presence of sharks along the east Australian coast was summarised by $0.25^{\circ}$ latitudinal bins. This was calculated by summing the overall number of ADPs (all sharks) per $0.25^{\circ}$ latitudinal bin and dividing that by the number of sharks detected in that bin. Data were summarised separately for both $\mathrm{ADP}_{\text {sat }}$ and $\mathrm{ADP}_{\mathrm{ac}}$. The resultant metrics were a measure of mean period of occupancy per latitudinal bin based on both satellite tracking and acoustic tag detection data.

The movement of SLRT-tagged sharks was further defined into periods of travelling and residency using hidden Markov models (HMMs) applied to the linear interpolated satellite positions (Patterson et al. 2009, Langrock et al. 2012, Zucchini et al. 2016). When resident, the track of a shark was characterised by a high turning angle and short linear distance between successive positions; when travelling, a shark was characterised by a low turning angle (more linear track) and longer linear distance between successive positions. The HMMs were fitted using the R-package 'moveHMM' (Michelot et al. 2015), which estimates parameters that describe the distribution of observed step lengths and turning angles derived from estimated locations and uses the Viterbi algorithm to identify a behavioural state (Zucchini et al. 2016).

Residency in the Port Stephens region of central NSW, previously identified as a nursery area for white sharks by Bruce \& Bradford (2012), was also examined by estimating the mean number of days per month that tagged sharks were detected by acoustic receivers deployed in the area (see Harasti et al. $2017 \mathrm{~b}$ for deployment locations). Additional residency days were included in these analyses where a tagged shark registered an $\mathrm{ADP}_{\text {sat }}$ within the nursery area but did not register an acoustic detection. The bounds of the nursery area for these analyses were identified from the distribution of HMM-defined residency behaviour based on $\mathrm{ADP}_{\text {sat }}$ data (see Section 3). To provide a monthly mean of detection days throughout the study period, the cumulative number of days that sharks were detected in the nursery area in each month was divided by the number of sharks detected during that month. A residency index (RI), similar to that used by Lee et 
al. (2015), was also calculated for each shark and defined as the number of $\mathrm{ADP}_{\mathrm{ac}}$ registered within the Port Stephens nursery area divided by the number of days between a shark's first and last detection along the entire coast. RI analyses were restricted to sharks where the period between first and last acoustic detection exceeded 1 yr $(n=23)$. RIs within the Port Stephens nursery area were compared between male and female sharks using a $t$-test after first testing for homoscedasticity with a Fisher's F-test.

In all analyses, statistical significance was determined at $\alpha=0.05$. Statistical analyses were performed using $\mathrm{R}$ statistical software version 3.1.1 ( $\mathrm{R}$ Development Core Team; www.r-project.org).

\section{RESULTS}

\subsection{Numbers of sharks tagged, sex ratio and sizes}

A total of 43 juvenile white sharks were tagged with internal acoustic tags between October 2008 and November 2015: 39 off Port Stephens and 4 off Corner Inlet. Of these sharks, 23 were also fitted with fin-mounted SLRTs (22 from Port Stephens; 1 from Corner Inlet). Sharks ranged from 1.7 to $3.2 \mathrm{~m} \mathrm{TL}$ $($ mean $=2.2 \mathrm{~m})$ at the time of tagging (Table 1$)$. The sex ratio of tagged sharks significantly favoured females (females:males $=28: 15 ; \chi^{2}=3.93, \mathrm{df}=1, \mathrm{p}=$ $0.047)$.

Of the 43 tagged juvenile white sharks, 40 were subsequently detected by either acoustic receivers or the ARGOS satellite network. Three acoustic-tagged sharks were not detected during the study period. Of these, 1 was captured $29 \mathrm{~d}$ after and $435 \mathrm{~km}$ from the location of tagging in a commercial fish trawl. It was released by the fishers but was not subsequently detected on any acoustic receiver. Another was captured and killed $25 \mathrm{~d}$ after tagging at Blacksmiths Beach $\left(33^{\circ} 4.5^{\prime} \mathrm{S}, 151^{\circ} 39.6^{\prime} \mathrm{E}\right)$ in the NSW SCP, and the third was first detected in January 2016, outside of the nominated study period. In addition, a further shark was captured and killed on 19 November 2014 at Bondi ( $\left.33^{\circ} 53.6^{\prime} \mathrm{S}, 151^{\circ} 16.7^{\prime} \mathrm{E}\right)$ in the NSW SCP, $11 \mathrm{mo}$ after being tagged (Table 1). This shark had previously been detected by several receivers between southern NSW and the IMOS Coffs Harbour line, including detections on the shoreward-most receiver of the IMOS Bondi line over the $4 \mathrm{~d}$ period immediately prior to its capture in the SCP net at Bondi Beach.

Mean time at liberty (number of days between tagging and last detection) was $623 \mathrm{~d}$ (range 33-1802 d; median 473 d). We tracked 24 sharks for periods greater than $1 \mathrm{yr}$, including 23 fitted with SLRT and/ or acoustic tags and 1 fitted with an SLRT which provided data over $536 \mathrm{~d}$ but whose acoustic tag appears to have failed (Table 1).

\subsection{Spatial scale of movements}

The movements of satellite-tracked sharks were confined to eastern Australia, ranging from southern Queensland to northeast Tasmania and across the Tasman Sea to New Zealand (Fig. 1). Sharks showed a clear delineation in their east-west movements through Bass Strait, with very few registered SLRT positions west of a line running due south from Wilson's Promontory across Bass Strait to northern Tasmania $\left(146^{\circ} 22.0^{\prime} \mathrm{E}\right)$. Acoustic data indicated the same range of spatial movements. Sharks recorded 181947 detections on 287 acoustic receivers ranging from southern Queensland to northeast Tasmania and included detections by receivers off Stewart Island in southern New Zealand (Fig. 1). However, a lack of receiver deployments west of Wilson's Promontory and through Bass Strait in general precluded assessment of further westerly movement from acoustic tag data. One shark (no. 22) travelled north from SE Victoria to the Port Stephens area of NSW in 2012, before returning to SE Victoria. In the following year, it travelled north as far as the southern Great Barrier Reef, Queensland, covering a cumulative distance of approximately $8500 \mathrm{~km}$ over its tracking period of $536 \mathrm{~d}$. In both years, shark 22 made excursions offshore east of Bass Strait and southern NSW of between 200 and $500 \mathrm{~km}$. Shark 35, tagged off the Port Stephens region, travelled south along the NSW coast to Bass Strait before heading offshore in a southeast direction and travelling across the Tasman Sea to Stewart Island, New Zealand, where it was also detected on acoustic receivers. The $1800 \mathrm{~km}$ crossing from Bass Strait to New Zealand, commenced in mid-February 2012, was highly linear and at a sustained rate of movement of approximately $4.7 \mathrm{~km} \mathrm{~h}^{-1}$. The SLRT attached to the dorsal fin of the shark failed shortly after reaching Stewart Island in early March, but the acoustic tag continued to be detected by receivers in the area for a period of 3 mo until June (Francis et al. 2015).

\subsection{Seasonal distribution}

Juvenile white sharks were recorded along the entire east coast from southern Queensland to north- 


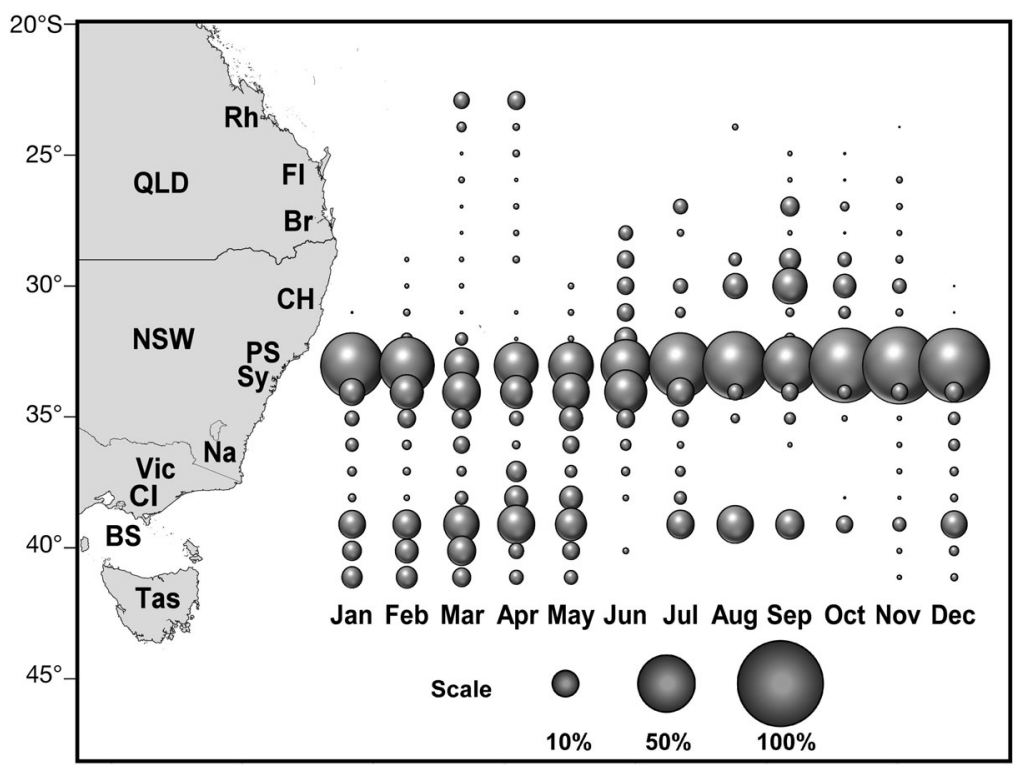

Fig. 2. Monthly distribution of juvenile white shark activity along the east Australian coast by latitudinal bins. Bubble size indicates the percentage distribution of average daily position based on satellite and acoustic tags $\left(\mathrm{ADP}_{\text {sat }}\right.$ and $\left.\mathrm{ADP}_{\mathrm{ac}}\right)$, combined by month (all data 20082015) per $1^{\circ}$ of latitude. Place name abbreviations as per Fig. 1

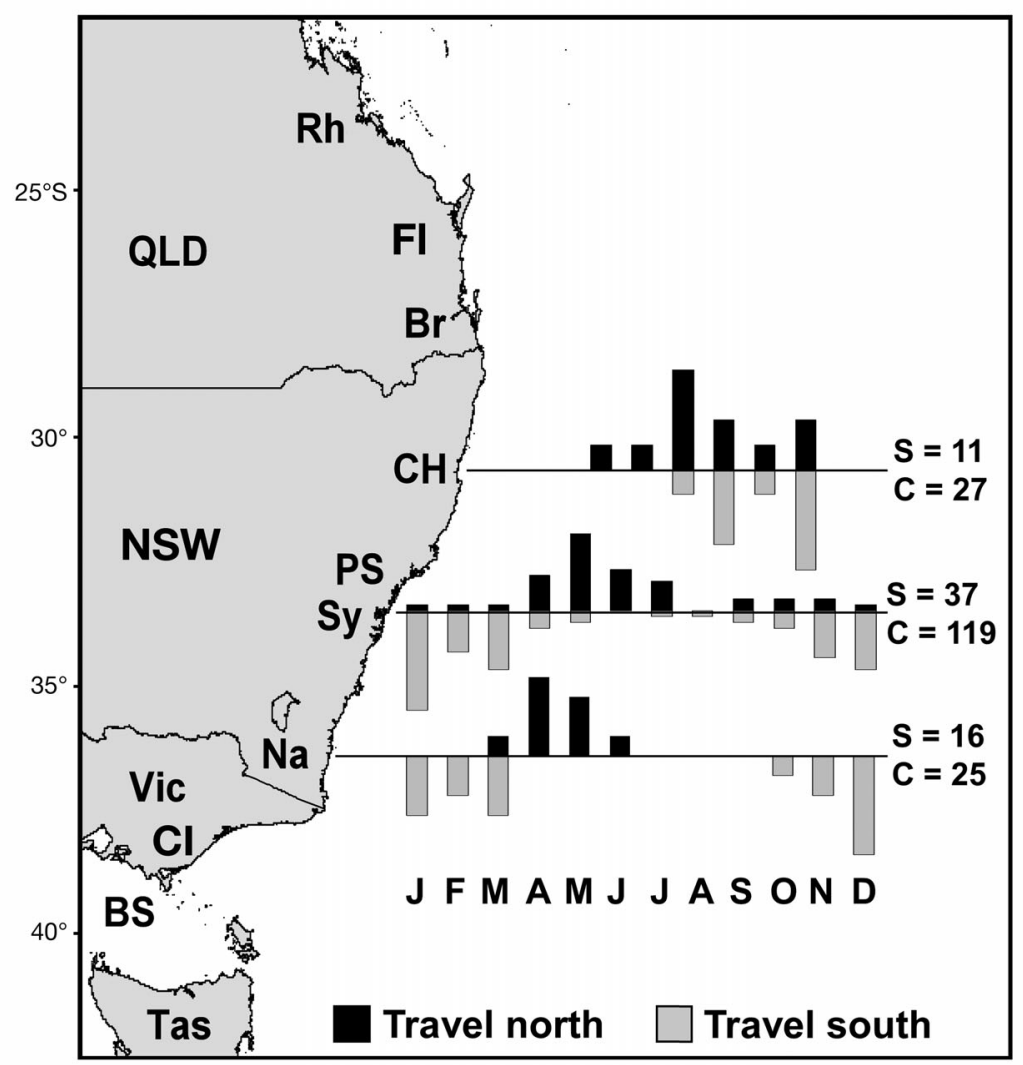

Fig. 3. Timing and direction of travel for white sharks crossing 3 cross shelf lines of receivers maintained by the Integrated Marine Observing System. S: numbers of sharks detected; C: number of crossings where direction of travel was determined. Place name abbreviations as per Fig. 1 ern Tasmania in most months of the year. However, there was a general pattern of sharks being more commonly distributed from central NSW to SE Victoria from December through to May, and from central NSW to SE Queensland from June to November (Fig. 2). Exceptions were apparent, with some sharks recorded as far north as the southern Great Barrier Reef, east of Rockhampton, in March-April, and with sharks recorded off SE Victoria in all months of the year except June. Sharks were recorded off northern NSW in most months of the year, with a peak in recorded ADPs from June to November. Sharks were recorded off central NSW in all months of the year.

Acoustic-tagged sharks were detected on each of the 3 IMOS cross-shelf lines of acoustic receivers. Eleven tagged sharks were detected by receivers on the northernmost Coffs Harbour Line, with 27 crossings registered over the period of the study (Fig. 3). Crossings occurred from June to November, peaking in a northward movement in August and showing a southerly movement peak in November. We detected 37 tagged sharks crossing the Bondi line off Sydney, with 119 crossings in total. Six sharks (5 females, 1 male) were detected on the innermost receiver closest to the NSW SCP. Some sharks made several crossings over multiple years. Crossings were primarily southward from November to March and northward from April to June. Relatively few crossings occurred from August to October. The more southerly located Narooma line registered 25 crossings by 16 sharks. Crossings were primarily southerly in October to March and northerly from April to June.

The monthly timing of white shark captures in the Queensland SCP peaks from July to November, following a similar pattern to the cumulative monthly detections on the northern-most Coffs Harbour line. Captures in the NSW SCP peak from October to March, coinciding with the peak period for southerly movement registered on the Bondi Line. However, the NSW SCP data do have some temporal bias, as the programme does not operate from May to September. 


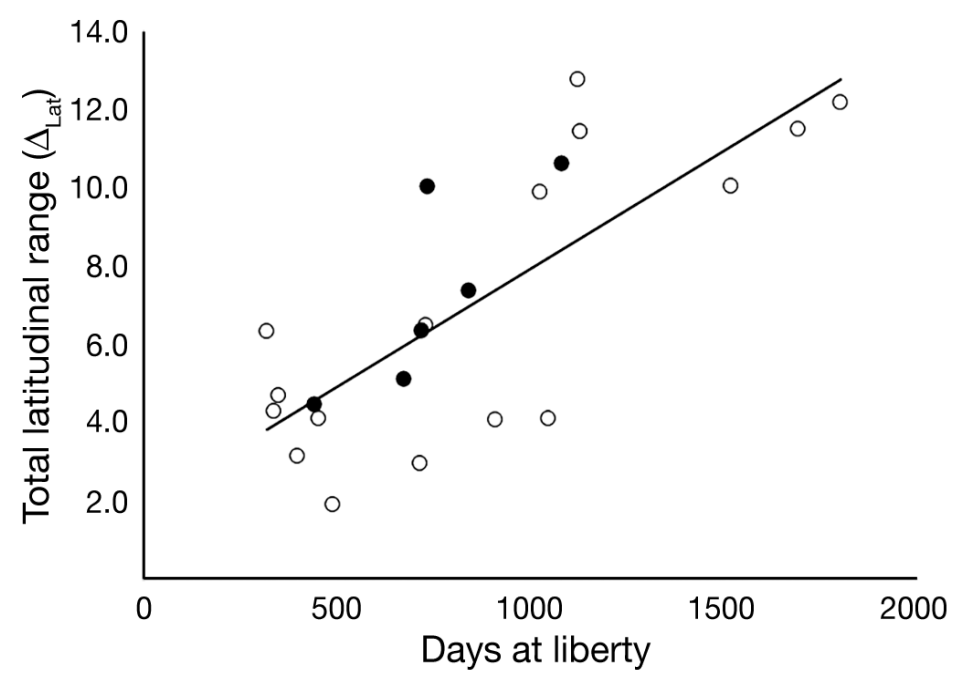

Fig. 4. Relationship between days at liberty and total latitudinal range of movements in degrees of latitude $\left(\Delta_{\text {Lat }}\right)$ for juvenile white sharks $<2.5 \mathrm{~m}$ total length at tagging and tracked over periods $>300 \mathrm{~d}$ in eastern Australia. Filled circles $=$ males; open circles $=$ females. The relationship is fitted by $y=0.006 x+1.884\left(r^{2}=0.58\right)$

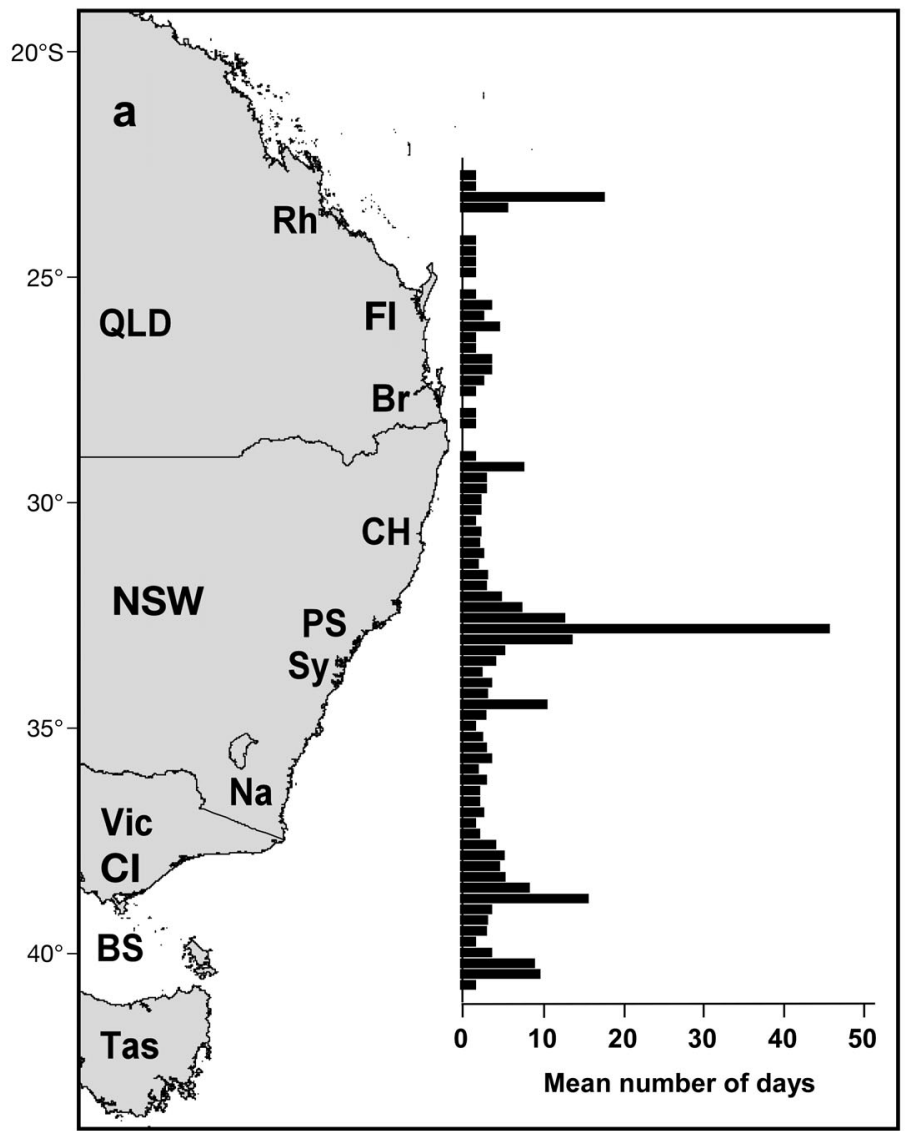

\subsection{Latitudinal range, travelling and residency}

There was a significant relationship between time at liberty and latitudinal range, for both sexes combined (Fig. 4 ; $\mathrm{r}^{2}=0.58$ ). Data were not analysed separately between sexes due to the lower number of males in the available sample set.

The presence of sharks was unevenly distributed by latitudinal bin along the coast, with several areas

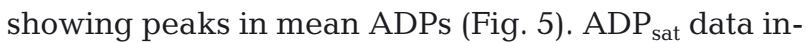
dicated main peak areas of occupancy east of Rockhampton (southern Queensland), Port Stephens (central NSW) and off SE Victoria, although the area off Rockhampton was influenced by data from a single shark. Several other areas also showed lower peaks in occupancy, including northern NSW, Wollongong just south of Sydney and off NE Tasmania. Data were sparse for $\mathrm{ADP}_{\mathrm{ac}}$ due to the distribution of receiver deployments. However, these data showed similar peaks in occupancy off Port Stephens and SE Victoria.

HMM-based areas of residency and travel, using $\mathrm{ADP}_{\text {sat, }}$ showed a similar pattern to latitudinal sum-

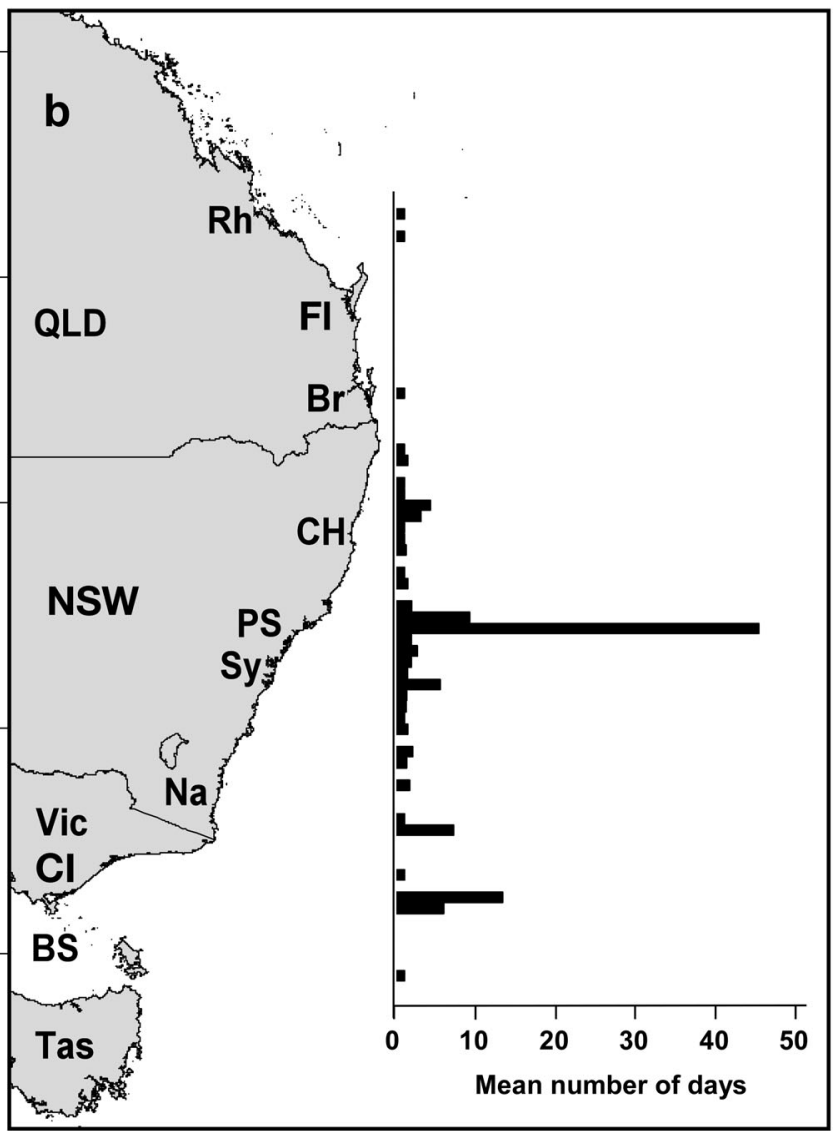

Fig. 5. Mean number of average daily positions by $0.25^{\circ}$ latitudinal bins recorded for (a) satellite-tracked $\left(A D P_{\text {sat }}\right)$ and (b) acoustic tagged juvenile white sharks $\left(\mathrm{ADP}_{\mathrm{ac}}\right)$. Place name abbreviations as per Fig. 1 


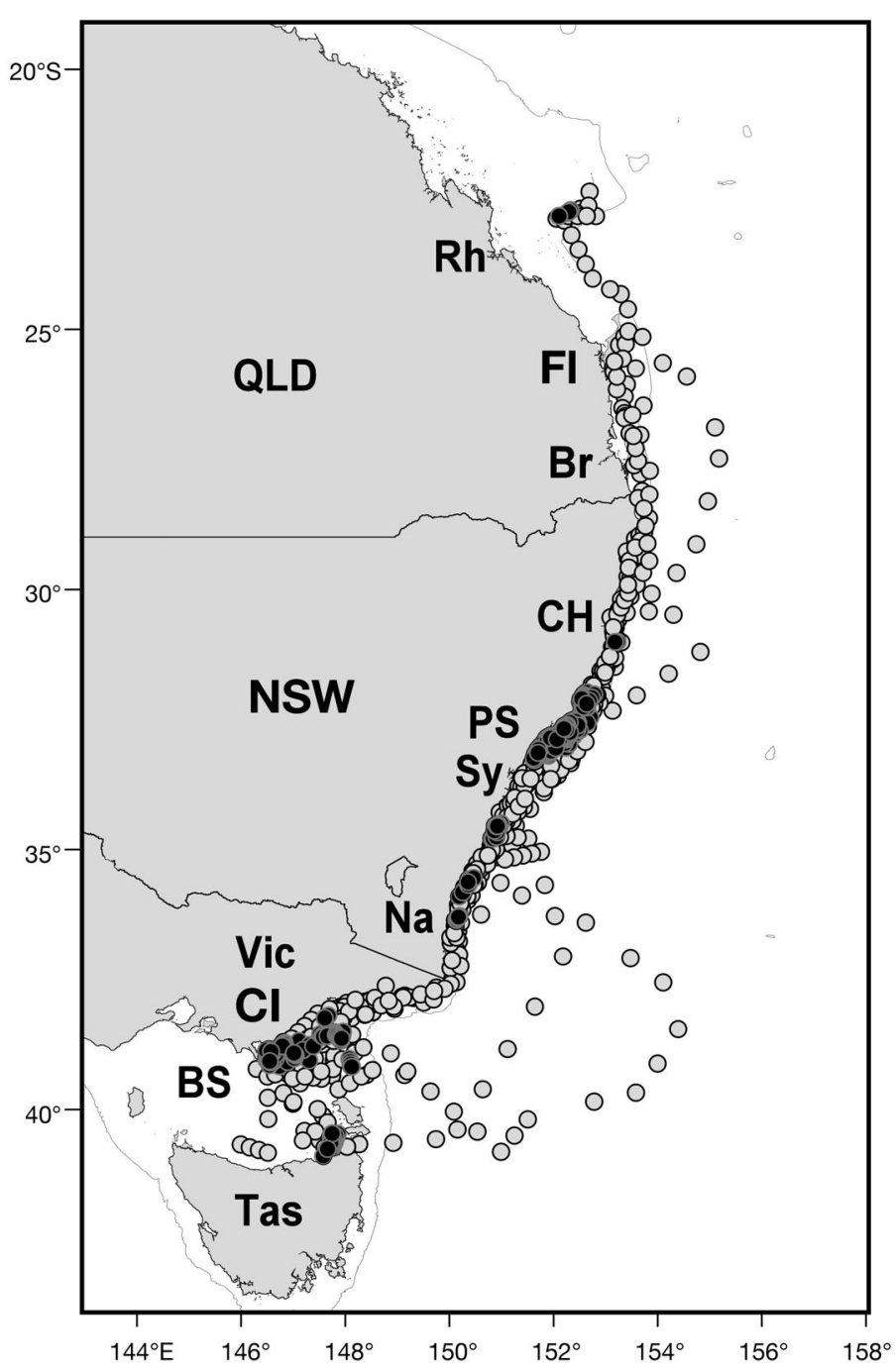

Fig. 6. Distribution of residency (black dots) and travelling states (grey dots) for tagged juvenile white sharks based on hidden Markov model analyses of data for average daily positions determined by satellites $\left(\mathrm{ADP}_{\text {sat }}\right)$. The $200 \mathrm{~m}$ depth contour is indicated by the solid line

maries (Fig. 6). The main areas of residency were centred around Port Stephens and SE Victoria, with lower level areas of residency dispersed along the coast including east of Rockhampton, mid-north NSW coast, areas south of Sydney and off NE Tasmania. The distribution of HMM residency states off Port Stephens defined a $90 \mathrm{~km}$ coastal strip bounded to the north by Treachery Head $\left(32^{\circ} 27.0^{\prime} \mathrm{S}\right)$, to the south by Newcastle $\left(32^{\circ} 57.0^{\prime} \mathrm{S}\right)$ and extending up to $35 \mathrm{~km}$ from shore. For the purpose of subsequent residency analyses, a shark was defined as being within the Port Stephens nursery area if it was detected on an acoustic receiver within these bounds.

\subsection{Residency and annual return to the Port Stephens nursery area}

Mean residency indices for males and females in the Port Stephens nursery area were not significantly different (mean male 0.12; mean female 0.19; $t$-test, $t=-1.281, \mathrm{p}=0.209$ ) and averaged 0.17 for the sexes combined. On an annual basis, this equated to a mean residency period of $62 \mathrm{~d} \mathrm{yr}^{-1}$. However, juvenile white sharks were detected within the nursery area in all months of the year. The monthly mean number of days that sharks were detected was lowest from March to April and generally peaked from October to January, although the specific timing of peaks and individual residency periods varied from year to year (Fig. 7). For example, shark 32 was detected in the nursery area for a near continuous period from 19 December 2012 to 29 October 2013. It was then recorded on receivers outside the nursery area followed by a return from 6 to 21 January 2014 .

Eighteen out of 39 sharks tagged in the Port Stephens nursery (46\%) made multi-year returns to the area. Six sharks were detected in 2 consecutive years; 6 were detected over 3 consecutive years; 4 were detected over 4 consecutive years and 1 was detected over 5 consecutive years. In addition, shark 12 was detected returning to the Port Stephens area in 4 years out of the 5 that it was monitored.

Nine sharks tagged in the Port Stephens nursery $(23 \%)$ were subsequently detected off SE Victoria in a region also identified as a nursery area by Bruce \& Bradford (2012). Three sharks tagged in SE Victoria $(75 \%)$ were detected in the Port Stephens nursery area, including 1 via SLRT only whose acoustic tag appears to have failed. The fourth tagged off SE Victoria was captured in commercial fishing operations and released off southern NSW but was not subsequently redetected.

\section{DISCUSSION}

This study examines the broad-scale and long-term movements of juvenile white sharks in eastern Australia, documenting their seasonal movement patterns. These data highlight the value of broad-scale, nationally and internationally collaborative acoustic receiver arrays and sustained monitoring of individual sharks over multi-year periods. The movements of tagged juvenile white sharks ranged from the southern Great Barrier Reef (approximately $22^{\circ} \mathrm{S}$ ) to northeast Tasmania and across the Tasman Sea to at least southern New Zealand (approximately $48^{\circ} \mathrm{S}$ ). 


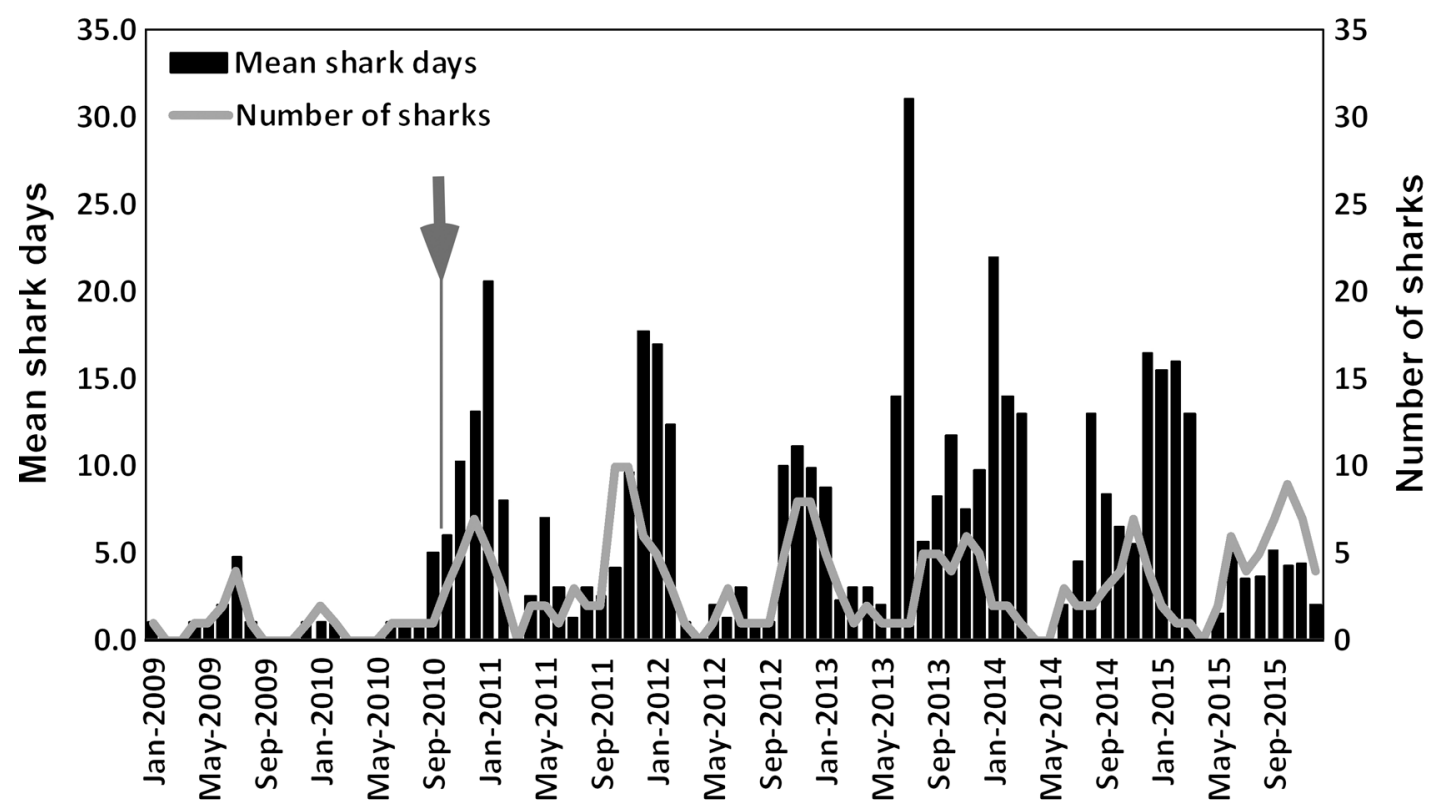

Fig. 7. Monthly mean detection days (black bars) and the number of sharks detected by month (grey line) on acoustic receivers in the Port Stephens, Australia, nursery area. Arrow denotes the deployment of a more extensive array of receivers than during the previous period (see Bruce et al. 2013)

This range is consistent with that documented by Bruce \& Bradford (2012), which was based on a smaller data set spanning a shorter time period $(24$ sharks tracked up to a maximum of only $225 \mathrm{~d}$ ).

In this study, sharks were tracked for a mean period of $623 \mathrm{~d}$, the largest tracking period being $1802 \mathrm{~d}$ $(\sim 5 \mathrm{yr})$, and with 24 individuals tracked for more than $1 \mathrm{yr}$. One shark's movements ranged from Tasmania to the Great Barrier Reef and return, travelling approximately $8500 \mathrm{~km}$ in $536 \mathrm{~d}$. Another shark was tracked crossing the Tasman Sea (also reported by Francis et al. 2015), further indicating a link between eastern Australia and New Zealand. No sharks were recorded travelling west of Bass Strait, which supports the 2-population model for Australasian white sharks suggested by Blower et al. (2012).

Most movements of juvenile white sharks were confined to shelf waters with occasional movements up to $100 \mathrm{~km}$ offshore. Only 2 sharks showed more extensive offshore movements; shark 22 made excursions up to $500 \mathrm{~km}$ offshore before returning to shelf waters, and shark 35 travelled to New Zealand. These sharks were 2 of the largest tagged $(2.8$ and $3.2 \mathrm{~m}$, respectively). White sharks show an ontogenetic shift from coastal, shelf-based waters to pelagic habitats in some areas (Domeier 2012, Skomal et al. 2017). Sub-adult (male: $3.0-3.6 \mathrm{~m}_{\text {i }}$ female: $3.0-4.8 \mathrm{~m}$ ) and adult (male: $>3.6 \mathrm{~m}$; female $>4.6 \mathrm{~m}$ ) white sharks are rarely encountered along the coastal strip of eastern Australia. However, satellite tracking undertaken in New
Zealand on these larger life stages has indicated extensive long-distance off-shore migrations as well as on-shelf occupancy near seal colonies (Francis et al. 2012). The behaviour observed in this study suggests that the size at which juveniles begin to move further offshore is between 2.5 and $3.0 \mathrm{~m}$, although Bruce \& Bradford (2012) reported a $2.1 \mathrm{~m}$ male white shark that crossed the Tasman Sea (see Fig. 1).

North-south movements of sharks were not always detected on the cross-shelf lines of IMOS acoustic receivers, indicating that sharks crossed the latitude of the array either close inshore or seaward of the receiver array, or they travelled across the lines without being detected. Only the Bondi IMOS line of receivers extended across the full width of the shelf during the study period. Satellite-tagged sharks were observed to occasionally make excursions of up to $500 \mathrm{~km}$ offshore and remain offshore over northsouth coastal distances of up to almost $600 \mathrm{~km}$. These offshore movements would obviously not be conducive to their detection by coastal receiver arrays and highlight the value of using both acoustic and satellite tracking technologies.

Although we observed a considerable degree of plasticity, the overall movements of juvenile white sharks were similar (1) regardless of the type or combination of electronic tag applied; (2) to the timing and seasonal peaks in concordance with the capture of non-tagged sharks in SCPs; and (3) to sharks tagged with non-electronic gamefish tags 
(see Bruce et al. 2006). Both this level of consistency and the longevity of tracking (up to $5 \mathrm{yr}$, i.e. some of the longest tracking periods achieved on individual white sharks) does not support theories expressed by some (see Hammerschlag et al. 2011) that the application of such electronic tags results in significant changes to movement behaviour.

Juvenile white sharks were recorded along most of the coast throughout the year. However, a seasonal signal of being in the northern region during winter-spring (June-November) and southern region during summer-autumn (December-May) was evident. Crossings of the northern-most Coffs Harbour line were most common during late winter-spring and on the southern-most Narooma line during summer and autumn. These timings of movement are consistent with the seasonal captures of untagged juvenile white sharks in both the NSW and Queensland SCPs. The peak time for captures in the NSW SCP occurs during spring when sharks are predominantly passing the Newcastle-Wollongong region heading southwards. This may indicate a more inshore route of sharks moving south. However, nets are not deployed from May to September and thus the potential for capture of sharks during their predominantly northern movement during the autumnwinter period is greatly reduced.

Our results are consistent with seasonal patterns observed in juvenile white sharks in other coastal areas. In the western North Atlantic, satellite-tagged juveniles predominately remained on the continental shelf $(<50 \mathrm{~m}$ depth) and moved from the northeast shelf in the boreal summer to inhabit waters off the south-eastern USA and the Gulf of Mexico during the winter (Skomal et al. 2017). In the north-east Pacific, young-of-the-year and sub-adult white sharks inhabit the southern Californian and Baja California, Mexico, coast (Weng et al. 2007b) throughout the year, but with a peak in abundance in California in late summer to autumn and the lowest occurrence in late winter to spring (Domeier 2012). Research from South Africa suggests that seasonal movement of white sharks is dependent on the location along the coast. White sharks of all sizes including juveniles were recorded in False Bay, Cape Town, year-round but showed seasonal sex-based aggregations at 2 different regions within the Bay, with females inhabiting inshore regions during the austral spring and summer (Kock et al. 2013). Further east along the South African coast, young-of-the-year and juvenile white sharks occurred inshore of Algoa Bay, Eastern Cape, during the austral spring and summer (Dicken \& Booth 2013).
The overall seasonal signal in movements suggests a response to an environmental cue, and several studies have linked the distribution of white sharks with water temperatures of around $18^{\circ} \mathrm{C}$ (Dewar et al. 2004, Bruce \& Bradford 2012, Weng et al. 2012). In eastern Australia, Lee et al. (2018) found that catches of white sharks in the NSW SCP were highest when sea surface temperatures (SST) were $\sim 17-18^{\circ} \mathrm{C}$, which is consistent with results from the KwaZuluNatal SCP (Wintner \& Kerwath 2018). Conversely, Werry et al. (2012) found no significant relationship between SST and white shark catch rates when combining data from both the NSW and Queensland SCPs. Because white sharks regulate their body temperature (Carey et al. 1982, Goldman 1997), the degree to which water temperature directly influences their distribution may be less important than other factors such as the distribution of their prey (Duffy et al. 2012), which in turn may well be temperature related. It is clear, however, that not all juvenile white sharks strictly adhere to a seasonal north-south movement cycle along the east coast of Australia.

Significantly more females were recorded in the inshore areas of Port Stephens during this study than males (ratio 1.87:1 females:males). An inshore bias towards females is also consistent with captures in SCPs along the eastern Australian coast and other regions. The sex ratio of white sharks captured in the Queensland SCP significantly favours females (females:males $=54: 34 ; \chi^{2}=4.54, \mathrm{df}=1, \mathrm{p}=0.033$ ), although captures in the NSW SCP favour females, the difference was not significant (females:males = $27: 21 ; \chi^{2}=0.75, \mathrm{df}=1, \mathrm{p}=0.386$; see also Krogh 1994 and Reid et al. 2011). Historical catches of juvenile white sharks in the KwaZulu-Natal (Cliff et al. 1989) SCPs have also recorded a female bias. While sexspecific patterns of occurrence have been well documented around pinniped colonies (Sosa-Nishizaki et al. 2012, Bruce \& Bradford 2015, Francis et al. 2015), this study suggests that an inshore bias towards females may be a consistent aspect of the species' early life history.

Sex-based differences in broad-scale movement patterns have been observed in other life history stages of white sharks. Domeier \& Nasby-Lucas (2012) found that females in the northeast Pacific use a larger, less defined offshore habitat than males. Bruce \& Bradford (2015) inferred differences in movement patterns between males and females based on seasonal patterns of arrival and departure of the sexes at the Neptune Islands, South Australia. Such observations are broadly consistent with sexbased differences in the presence of white sharks at 
various pinniped colonies world-wide (Bruce \& Bradford 2015).

Sex-based habitat use would have important management implications if an inshore habitat preference resulted in juvenile females being more vulnerable to coastal threats (e.g. fishing mortality or shark mitigation strategies) than males. For example, 5 out of 6 juvenile white sharks detected on the inner-most IMOS receiver of the Bondi cross shelf line and closest to the SCP-meshed beach of Bondi were female. However, to date, close-kin mark-recapture analyses remain consistent with a 50:50 adult sex ratio for the east Australian population of white sharks (Hillary et al. 2018).

The increase in latitudinal range with time at liberty (a proxy of age/growth) observed in this study is consistent with observations in other areas of the species' range. Klimley (1985) reported an increase in latitudinal range in juvenile white sharks off California and proposed that younger sharks were thermally limited in their movements. These findings were supported by Weng et al. (2007b), who also observed a niche expansion of larger juvenile white sharks into cooler waters both vertically and geographically. However, oceanographic conditions off California offer a more pronounced temperature range with latitude than off eastern Australia, and disentangling possible thermal limitation effects from movements related to varying prey selection as sharks increase in size is difficult to reconcile from our current data.

HMM-based analyses and overall patterns of latitudinal distribution were consistent with a 2-nursery area model for the east coast of Australia in coastal waters off Port Stephens, NSW, and SE Victoria (Bruce \& Bradford 2012), but also indicated multiple short-term areas of temporary residency along the east coast. The footprint of the Port Stephens nursery area was slightly larger than that reported by Bruce \& Bradford (2012), extending $90 \mathrm{~km}$ along the NSW coastline from Newcastle to Treachery Head. Juvenile white sharks made repeated annual visits to both nursery areas. Sharks visited the Port Stephens nursery area for up to 5 consecutive years following tagging, although peak residency times varied between years. The area east of Rockhampton, Queensland, where 1 shark was temporarily resident, is an area regularly visited by white sharks tagged in other programmes (Bruce et al. 2006, Duffy et al. 2012, Francis et al. 2015) and thus may be an additional important residency area for the species in eastern Australia.

Movement between the east coast nursery areas and across the Tasman Sea was dominated by rapid and direct travel, with rates of movement up to $4.7 \mathrm{~km} \mathrm{~h}^{-1}$. These rates are consistent with other studies. McAuley et al. (2017) estimated that a $1.8 \mathrm{~m}$ (TL) male white shark travelled at a rate of $5.6 \mathrm{~km} \mathrm{~h}^{-1}$ covering $193 \mathrm{~km}$ in only $35 \mathrm{~h}$. A further 25 sharks were estimated to have rates of movement of over $3 \mathrm{~km} \mathrm{~h}^{-1}$ for distances between 103 and $3362 \mathrm{~km}$. Domeier \& Nasby-Lucas (2008) showed that adult white sharks travelled along a migration corridor offshore into the eastern Pacific at speeds of approximately $3.2 \mathrm{~km} \mathrm{~h}^{-1}$, suggesting that rapid, direct, longdistance movements are relatively common for this species.

Juvenile white sharks were detected in the Port Stephens region throughout the year, although there was a strong seasonal pattern in both occupancy (number of days per month) and abundance. The estimated annual residency of sharks in the Port Stephens nursery area calculated during this study was similar to that estimated by Bruce \& Bradford (2012) and did not differ between the sexes. However, monthly mean detection may underestimate true residency, as receivers were not deployed to monitor the entire nursery area and thus data refer only to that area monitored, which was heavily biased to nearshore and estuarine waters.

This study has examined the movements of acoustic and satellite tagged white sharks Carcharodon carcharias off the eastern seaboard of Australia to improve our understanding of their temporal patterns and spatial extent as well as to inform conservation management policy and human-shark interaction risk management strategies. We have documented extensive movements along the eastern seaboard and across the Tasman Sea to New Zealand and have identified sex-based differences in habitat use and an increase in latitudinal range of movement with size/ age. Further long-term tracking of juvenile white sharks in eastern Australia will help identify if females, in particular, are more vulnerable to inshore anthropogenic pressures. Long-term monitoring of acoustic-tagged sharks via data sharing through collaborative national and international receiver arrays offers future promise to examine movements over periods relevant to further ontogenetic changes and at scales providing context to interannual variability.

Acknowledgements. This work was undertaken for the Marine Biodiversity Hub, a collaborative partnership supported through funding from the Australian Government's National Environmental Science Programme (NESP). NESP Marine Biodiversity Hub partners include the Institute for Marine and Antarctic Studies, University of Tasmania; CSIRO, Geo- 
science Australia, Australian Institute of Marine Science, Museum Victoria, Charles Darwin University, University of Western Australia, NSW Office of Environment and Heritage, NSW Department of Primary Industries and the Integrated Marine Observing System (IMOS). Additional acoustic tag detection data was sourced from IMOS, which is supported by the Australian Government through the National Collaborative Research Infrastructure Strategy and the Super Science Initiative. Tagging of sharks and collection of samples were approved under Tasmanian Department of Primary Industries, Parks, Water and the Environment (DPIPWE) AEC Project 1/2013-14 (and previous derivations), DPIPWE Living Marine Resources Management Act 1995 Permit 15008 (and previous derivations), DPIPWE Threatened Fauna for Scientific Purposes permit 14239; Victorian Department of Environment and Primary Industries (DEPI) Research permit 10006912, VDPI Protected Aquatic Biota permit PA38; New South Wales Department of Primary Industries (NSW DPI) Animal Care and Ethics permit ACEC 14/07 and NSW DPI Scientific Collection permit P07/0099. We thank Kent Stannard, Bob Creese, Brett Louden, Vic Peddemors, Brian Hughes, Ashley Leedman, Toby Patterson, John O'Sullivan, Michael Domeier, Tag for Life, Hunter-Central Rivers Catchment Management Authority, Northern Rivers Catchment Management Authority, Sydney Aquarium Conservation Fund, Melbourne Aquarium and the Monterey Bay Aquarium for assistance and additional support during the study period.

\section{LITERATURE CITED}

Andrews AH, Kerr LA (2015) Validated age estimates for large white sharks of the northeastern Pacific Ocean: altered perceptions of vertebral growth shed light on complicated bomb $\Delta^{14} \mathrm{C}$ results. Environ Biol Fishes 98: 971-978

Andrews KS, Williams GD, Levin PS (2010) Seasonal and ontogenetic changes in movement patterns of six-gill sharks. PLOS ONE 5:e12549

Arnold G, Dewar H (2001) Electronic tags in marine fisheries research: a 30-year perspective. In: Sibert JR, Nielsen JL (eds) Electronic tagging and tracking in marine fisheries: Proc Symp Tag Track Mar Fish Electron Devices, Feb 7-11, 2000, East-West Center, University of Hawaii. Springer, Dordrecht, p 1-6

Blower DC, Pandolfi JM, Bruce BD, Gomez-Cabrera MdC, Ovenden JR (2012) Population genetics of Australian white sharks reveals fine-scale spatial structure, transoceanic dispersal events and low effective population sizes. Mar Ecol Prog Ser 455:229-244

Bonfil R, Meyer M, Scholl MC, Johnson R and others (2005) Transoceanic migration, spatial dynamics, and population linkages of white sharks. Science 310:100-103

Bradford RW, Hobday AJ, Bruce BD (2012) Identifying juvenile white shark behaviour from electronic tag data. In: Domeier ML (ed) Global perspectives on the biology and life history of the white shark. CRC Press, Boca Raton, FL, p 255-270

Bruce BD (2008) The biology and ecology of the white shark, Carcharodon carcharias. In: Pikitch E, Camhi M (eds) Sharks of the open ocean: biology, fisheries and conservation. Blackwell Scientific, London, p 69-81

Bruce BD, Bradford RW (2012) Habitat use and spatial dynamics of juvenile white sharks, Carcharodon car- charias, in eastern Australia. In: Domeier ML (ed) Global perspectives on the biology and life history of the white shark. CRC Press, Boca Raton, FL, p 225-253

*Buce B, Bradford R (2015) Segregation or aggregation? Sex specific patterns in the seasonal occurrence of white sharks Carcharodon carcharias at the Neptune Islands, South Australia. J Fish Biol 87:1355-1370

* Bruce BD, Stevens JD, Malcolm H (2006) Movements and swimming behaviour of white sharks (Carcharodon carcharias) in Australian waters. Mar Biol 150:161-172

Bruce BD, Bradford RW, Hughes B, Carraro R, Gallen C, Harasti D, Gladstone W (2013) Acoustic tracking and aerial surveys of juvenile white sharks in the Hunter Catchment Management Authority region. Final Report. CSIRO, Hobart

Calenge C (2006) The package 'adehabitat' for the R software: a tool for the analysis of space and habitat use by animals. Ecol Model 197:516-519

Carey FG, Kanwisher J, Brazier O, Gabrielson G, Casey J, Pratt H Jr (1982) Temperature and activities of a white shark, Carcharodon carcharias. Copeia 1982:254-260

* Carlisle AB, Starr RM (2009) Habitat use, residency, and seasonal distribution of female leopard sharks Triakis semifasciata in Elkhorn Slough, California. Mar Ecol Prog Ser 380:213-228

* Chapman DD, Feldheim KA, Papastamatiou YP, Hueter RE (2015) There and back again: a review of residency and return migrations in sharks, with implications for population structure and management. Annu Rev Mar Sci 7: $547-570$

Cliff G, Dudley SFJ, Davis B (1989) Sharks caught in the protective gill nets off Natal, South Africa. II. The great white shark Carcharodon carcharias (Linnaeus). S Afr J Mar Sci 8:131-144

* Crossin GT, Heupel MR, Holbrook CM, Hussey NE and others (2017) Acoustic telemetry and fisheries management. Ecol Appl 27:1031-1049

* Dewar H, Domeier M, Nasby-Lucas N (2004) Insights into young of the year white shark, Carcharodon carcharias, behavior in the Southern California Bight. Environ Biol Fish 70:133-143

* Dicken ML, Booth AJ (2013) Surveys of white sharks (Carcharodon carcharias) off bathing beaches in Algoa Bay, South Africa. Mar Freshw Res 64:530-539

* Doherty PD, Baxter JM, Gell FR, Godley BJ and others (2017) Long-term satellite tracking reveals variable seasonal migration strategies of basking sharks in the northeast Atlantic. Sci Rep 7:42837

Domeier ML (2012) A new life-history hypothesis for white sharks, Carcharodon carcharias, in the North Eastern Pacific. In: Domeier ML (ed) Global perspectives on the biology and life history of the white shark. CRC Press, Boca Raton, FL, p 199-224

* Domeier ML, Nasby-Lucas N (2008) Migration patterns of white sharks Carcharodon carcharias tagged at Guadalupe Island, Mexico, and identification of an eastern Pacific shared offshore foraging area. Mar Ecol Prog Ser 370:221-237

Domeier ML, Nasby-Lucas N (2012) Sex specific migration patterns and sexual segregation for adult white sharks in the north eastern Pacific. In: Domeier ML (ed) Global perspectives on the biology and life history of the white shark. CRC Press, Boca Raton, FL, p 133-146

Duffy CAJ, Francis MP, Manning MJ, Bonfil R (2012) Regional population connectivity, oceanic habitat, and 
return migration revealed by satellite tagging of white sharks, Carcharodon carcharias, at New Zealand aggregation sites. In: Domeier ML (ed) Global perspectives on the biology and life history of the white shark. CRC Press, Boca Raton, FL, p 301-318

Francis MP, Duffy CAJ, Bonfil R, Manning MJ (2012) The third dimension: vertical habitat use by white sharks, Carcharodon carcharias, in New Zealand and in oceanic and tropical waters of the southwest Pacific Ocean. In: Domeier ML (ed) Global perspectives on the biology and life history of the white shark. CRC Press, Boca Raton, FL, p 319-342

Francis MP, Duffy C, Lyon W (2015) Spatial and temporal habitat use by white sharks (Carcharodon carcharias) at an aggregation site in southern New Zealand. Mar Freshw Res 66:900-918

Goldman KJ (1997) Regulation of body temperature in the white shark, Carcharodon carcharias. J Comp Physiol B 167:423-429

Gubili C, Duffy CA, Wintner SP, Shivji MS and others (2012) Application of molecular genetics for conservation of the white shark, Carcharodon carcharias, L. 1758. In: Domeier ML (ed) Global perspectives on the biology and life history of the white shark. CRC Press, Boca Raton, FL, p 357-380

Hammerschlag N, Gallagher AJ, Lazarre DM (2011) A review of shark satellite tagging studies. J Exp Mar Biol Ecol 398:1-8

Harasti D, Lee KA, Gallen C, Hughes JM, Stewart J (2015) Movements, home range and site fidelity of snapper (Chrysophrys auratus) within a temperate marine protected area. PLOS ONE 10:e0142454

* Harasti D, Lee KA, Laird R, Bradford R, Bruce B (2017a) Use of stereo baited remote underwater video systems to estimate the presence and size of white sharks (Carcharodon carcharias). Mar Freshw Res 68:1391-1396

Harasti D, Lee K, Bruce B, Gallen C Bradford R (2017b) Juvenile white sharks Carcharodon carcharias use estuarine environments in south-eastern Australia. Mar Biol 164:58

Heupel MR, Semmens JM, Hobday AJ (2006) Automated acoustic tracking of aquatic animals: scales, design and deployment of listening station arrays. Mar Freshw Res 57:1-13

Heupel MR, Carlson JK, Simpfendorfer CA (2007) Shark nursery areas: concepts, definition, characterization and assumptions. Mar Ecol Prog Ser 337:287-297

Heupel MR, Simpfendorfer CA, Espinoza M, Smoothey AF, Tobin A, Peddemors V (2015) Conservation challenges of sharks with continental scale migrations. Front Mar Sci $2: 12$

*Hillary RM, Bravington MV, Patterson TA, Grewe P and others (2018) Genetic relatedness reveals total population size of white sharks in eastern Australia and New Zealand. Sci Rep 8:2661

Hueter RE, Heupel MR, Heist EJ, Keeney DB (2005) Evidence of philopatry in sharks and implications for the management of shark fisheries. J Northw Atl Fish Sci 35: 239-247

Klimley AP (1985) The areal distribution and autoecology of the white shark, Carcharodon carcharias, off the west coast of North America. Mem South Calif Acad Sci 9:15-40

Knip DM, Heupel MR, Simpfendorfer CA (2010) Sharks in nearshore environments: models, importance, and consequences. Mar Ecol Prog Ser 402:1-11

Kock A, O'Riain MJ, Mauff K, Meÿer M, Kotze D, Griffiths C
(2013) Residency, habitat use and sexual segregation of white sharks, Carcharodon carcharias in False Bay, South Africa. PLOS ONE 8:e55048

* Krogh M (1994) Spatial, seasonal and biological analysis of sharks caught in the New South Wales protective beach meshing programme. Mar Freshw Res 45:1087-1106

* Langrock R, King R, Matthiopoulos J, Thomas L, Fortin D, Morales JM (2012) Flexible and practical modeling of animal telemetry data: hidden Markov models and extensions. Ecology 93:2336-2342

Last PR, Stevens JD (2009) Sharks and rays of Australia, $2^{\text {nd }}$ edn. CSIRO, Collingwood

*Lee KA, Huveneers C, Macdonald T, Harcourt RG (2014) Size isn't everything: movements, home range, and habitat preferences of eastern blue gropers (Achoerodus viridis) demonstrate the efficacy of a small marine reserve. Aquat Conserv 2014:174-186

* Lee KA, Huveneers C, Peddemors V, Boomer A, Harcourt RG (2015) Born to be free? Assessing the viability of releasing captive-bred wobbegongs to restock depleted populations. Front Mar Sci 2:18

* Lee KA, Roughan M, Harcourt RG, Peddemors VM (2018) Environmental correlates of relative abundance of potentially dangerous sharks in nearshore areas, southeastern Australia. Mar Ecol Prog Ser 599:157-179

Lyon BJ, Dwyer RG, Pillans RD, Campbell HA, Franklin CE (2017) Distribution, seasonal movements and habitat utilisation of an endangered shark, Glyphis glyphis, from northern Australia. Mar Ecol Prog Ser 573:203-213

* Martin RA, Hammerschlag N, Collier RS, Fallows C (2005) Predatory behaviour of white sharks (Carcharodon carcharias) at Seal Island, South Africa. J Mar Biol Assoc UK 85:1121-1135

*McAuley RB, Bruce BD, Keay IS, Mountford S, Pinnell T, Whoriskey FG (2017) Broad-scale coastal movements of white sharks off Western Australia described by passive acoustic telemetry data. Mar Freshw Res 68:1518-1531

Michelot T, Langrock R, Patterson T, Rexstad E (2015) moveHMM: animal movement modelling using Hidden Markov Models. R package version 1.1.

* Oñate-González EC, Sosa-Nishizaki O, Herzka SZ, Lowe CG and others (2017) Importance of Bahia Sebastian Vizcaino as a nursery area for white sharks (Carcharodon carcharias) in the Northeastern Pacific: a fishery dependent analysis. Fish Res 188:125-137

*Pardini AT, Jones CS, Noble LR, Kreiser B and others (2001) Sex-biased dispersal of great white sharks. Nature 412: 139-140

Patterson TA, Basson M, Bravington MV, Gunn JS (2009) Classifying movement behaviour in relation to environmental conditions using Hidden Markov Models. J Anim Ecol 78:1113-1123

* Queiroz N, Humphries NE, Mucientes G, Hammerschlag N and others (2016) Ocean-wide tracking of pelagic sharks reveals extent of overlap with longline fishing hotspots. Proc Natl Acad Sci USA 113:1582-1587

* Reid DD, Robbins WD, Peddemors VM (2011) Decadal trends in shark catches and effort from the New South Wales, Australia, Shark Meshing Program 1950-2010. Mar Freshw Res 62:676-693

Robbins RL (2007) Environmental variables affecting the sexual segregation of great white sharks Carcharodon carcharias at the Neptune Islands South Australia. J Fish Biol 70:1350-1364

Ruppert JLW, Travers MJ, Smith LL, Fortin MJ, Meekan MG 
(2013) Caught in the middle: combined impacts of shark removal and coral loss on the fish communities of coral reefs. PLOS ONE 8:e74648

Simpfendorfer CA, Heupel MR, Heuter RE (2002) Estimation of short-term centers of activity from an array of omnidirectional hydrophones and its use in studying animal movements. Can J Fish Aquat Sci 59:23-32

Sims DW, Southall EJ, Tarling GA, Metcalfe JD (2005) Habitat-specific normal and reverse diel vertical migration in the plankton-feeding basking shark. J Anim Ecol 74: 755-761

Skomal GB, Braun CD, Chisholm JH, Thorrold SR (2017) Movements of the white shark Carcharodon carcharias in the North Atlantic Ocean. Mar Ecol Prog Ser 580: $1-16$

Sosa-Nishizaki O, Morales-Bojorquez E, Nasby-Lucas N, Onate-Gonzalez EC, Domeier ML (2012) Problems with photo identification as a method of estimating abundance of white sharks, Carcharodon carcharias. In: Domeier ML (ed) Global perspectives on the biology and life history of the white shark. CRC Press, Boca Raton, FL, p 393-404

Welch DW, Turo S, Batten SD (2006) Large-scale marine and freshwater movements of white sturgeon. Trans Am Fish Soc 135:386-389

Weng KC, Boustany AM, Pyle P, Anderson SD, Brown A, Block BA (2007a) Migration and habitat of white sharks (Carcharodon carcharias) in the eastern Pacific Ocean. Mar Biol 152:877-894

Editorial responsibility: Elliott Hazen,

Pacific Grove, California, USA
Weng KC, O'Sullivan JB, Lowe CG, Winkler CE, Dewar H, Block BA (2007b) Movements, behavior and habitat preferences of juvenile white sharks Carcharodon carcharias in the eastern Pacific. Mar Ecol Prog Ser 338:211-224

Weng KC, O'Sullivan JB, Lowe CG, Winkler CE and others (2012) Back to the wild: release of juvenile white sharks from the Monterey Bay Aquarium. In: Domeier ML (ed) Global perspectives on the biology and life history of the white shark. CRC Press, Boca Raton, FL, p 419-446

Werry JM, Bruce BD, Sumpton W, Reid D, Mayer DG (2012) Beach areas used by juvenile white sharks, Carcharodon carcharias, in eastern Australia. In: Domeier ML (ed) Global perspectives on the biology and life history of the white shark. CRC Press, Boca Raton, FL, p 271-286

*Wilson SG, Polovina JJ, Stewart BS, Meekan MG (2006) Movements of whale sharks (Rhincodon typus) tagged at Ningaloo Reef, Western Australia. Mar Biol 148: 1157-1166

Wintner SP, Kerwath SE (2018) Cold fins, murky waters and the moon: What affects shark catches in the bather-protection program of KwaZulu-Natal, South Africa? Mar Freshw Res 69:167-177

Witt MJ, Åkesson S, Broderick AC, Coyne MS and others (2010) Assessing accuracy and utility of satellite-tracking data using Argos-linked Fastloc-GPS. Anim Behav 80: $571-581$

Zucchini W, Macdonald IL, Langrock R (2016) Hidden Markov models for time series: an introduction using $\mathrm{R}$. CRC Press, Boca Raton, FL

Submitted: April 9, 2018; Accepted: April 17, 2019

Proofs received from author(s): May 23, 2019 